Abditani : Jurnal Pengabdian Masyarakat 2 (2) 67-72

e-ISSN : 2622-4690

p-ISSN : 2622-4682

\title{
PELATIHAN DAN PENDAMPINGAN INOVASI OLAHAN UMBI SINGKONG (Manihot spp.) BAGI PELAKU UMKM SEKTOR USAHA KAKI LIMA DI SALATIGA
}

\author{
Sarlina Palimbong ${ }^{1,2^{*}}$, Brigitte Sarah Renyoet ${ }^{1}$, Markus Hulu $^{1}$, Galih Arian Nugraha ${ }^{1}$, Maria \\ Kristina Anggraeni ${ }^{1}$
}

\author{
${ }^{1}$ Program Studi Teknologi Pangan, Fakultas Kedokteran dan Ilmu Kesehatan, Universitas Kristen Satya \\ Wacana, Jl. Diponegoro, Jl. Kartini No. 11A, Salatiga 50711 \\ ${ }^{2}$ Pusat Studi Pangan Fungsional, Universitas Kristen Satya Wacana; Jl. Diponegoro 52 - 60 Kec. \\ Sidorejo, Kota Salatiga, Jawa Tengah, Salatiga, telp(0298) 321212 \\ e-mail: ${ }^{1,2 *}$ sarlina.palimbong@uksw.edu, ${ }^{1}$ brigitte.renyoet@uksw.edu, ${ }^{1} 492018015 @$ @ student.uksw.edu, \\ 1492018004@student.uksw.edu, ${ }^{1} 492015003 @$ student.uksw.edu
}

\begin{abstract}
ABSTRAK
Kegiatan pelatihan dan pendampingan inovasi olahan umbi singkong bagi pelaku UMKM sector kaki lima telah di lakukan di Salatiga pada bulan April 2019. Kegiatan ini rutin dilakukan sebagai bentuk kerjasama Pemerintah Kota Salatiga yaitu Dinas Koperasi, Usaha Kecil dan Menengah dengan Fakultas Kedokteran dan Ilmu Kesehatan Universitas Kristen Satya Wacana, Salatiga. Tujuan kegiatan ini adalah untuk memberikan edukasi kepada para peserta terpilih mengenai potensi singkong secara umum dan memberikan keterampilan tambahan untuk membuat olahan makanan yang bersumber dari bahan pangan yang mudahditemui di Salatiga seperti singkong sehingga dapat meningkatkan kuantitas dan kualitas produk yang dihasilkan. Metode kegiatan dilakukan dalam dua tahap: tahap pertama sesi penyuluhan tentang inovasi olahan umbi singkong, dan tahap kedua adalah pelatihan pembuatan menu olahan umbi singkong yang inovatif. Respon peserta sangat antusias karena banyak mendapat pengetahuan dan pengalaman baru selama kegiatan ini berlangsung, sebagian besar menyatakan mendapatkan ide baru untuk inovasi produk dagangannya dan meminta agar diadakan lagi kegiatan semacam ini serta ada pendampingan langsung dari pemateri di kelas terutama kelas inovasi pangan.
\end{abstract}

Kata kunci: inovasi singkong; pelatihan; pendampingan UMKM

\section{Pendahuluan}

Umbi dalam pengertiannya dikenal sebagai bagian tanaman yang mengalami pembesaran dalam tanah. Umumnya bagian ini kaya pati. Tanaman singkong (Manihot spp) merupakan tanaman penghasil umbi yang populer di seluruh dunia terutama di negara-negara berkembang seperti di Amerika Selatan, Afrika, dan Asia (Montero, 2003). Sejak dulu, umbi singkong dikenal sebagai sumber kalori terbesar keempat di dunia (Chavarriaga-Aguirre et al., 2016), pakan ternak (Morgan \& Choct, 2016), dan daunnya dikonsumsi sebagai sayuran tinggi protein, mineral, dan vitamin (Latif \& Müller, 2015). Singkong kaya karbohidrat yang mampu mengenyangkan manusiadipandang lebih sehat daripada mengonsumsi beras ataupun gandum. Hal ini dapat dipahami sebab karbohidrat kompleks lebih lama terpecah menjadi gula - gula sederhana sehingga mengenyangkan lebih lama dibandingkan sumber karbohidrat lainnya. Gandum kaya protein (gluten) yang berakibat negatif jika dikonsumsi oleh penderita Autis dan Celiac. Selain itu, harga singkong lebih murah dibanding kedua komoditi diatas menjadikan singkong dipandang sebagai makanan kelas menengah kebawah. Singkong dapat diolah menjadi beragam panganan baik tradisional maupun modern. Singkong mudah tumbuh dilingkungan manapun tanpa mengenal musim, tidak memerlukan pemeliharaan khusus, sehingga mudah mudah dipanen sesuai kebutuhan (Cardoso et al., 2005), Mudah dijumpai di pasar tradisional dengan harga yang sangat terjangkau. 
Pemilihan materi tentang potensi singkong secara umum disampaikan sebagai kelanjutan dari materi kegiatan serupa sebelumnya namun dengan peserta yang berbeda. Berawal dari semakin meningkatnya permintaan industri pangan di Indonesia akan terigu dan olahannya yang membuat sumbersumber pati lainnya cenderung terabaikan padahal sumbernya sangat mudah diperoleh disekitar kita (Palimbong, Nurwarista, \& Istimur, 2019). Melalui kegiatan rutin ini penulis ingin membuka wawasan pelaku usaha agar mau melirik sumber-sumber pati lainnya selain terigu untuk digunakan dalam usaha dagangnya sehingga lama kelamaan dapat mengurangi ketergantungan Indonesia akan terigu.

Kegiatan pengabdian ini diadakan sebagai respon dari tanggung jawab sosial pendidik untuk turut serta memberikan wawasan kependidikan dengan tujuan peningkatan kualitas diri masyarakat. Program Studi Teknologi Pangan, Fakultas Kedokteran dan Ilmu Kesehatan (FKIK), Universitas Kristen Satya Wacana (UKSW) mendapatkan kesempatan untuk melakukan kolaborasi kegiatan dengan Dinas Koperasi, Usaha Kecil, dan Menengah Pemerintah Kota Salatiga. Kolaborasi kegiatan tersebut merupakan salah satu bentuk realisasi dari kerjasama yang dijalin oleh kedua belah pihak. Bentuk kegiatan yang dilakukan yaitu penyuluhan dan pelatihan.

\section{Masalah}

Berdasarkan hasil diskusi peserta pada sesi awal, beberapa kendala yang ditemui dalam kegiatan usaha seperti: terbatasnya pengetahuan olahan berbasis singkong, susu, dan daging sehingga hanya dibuat menjadi produk standar dengan harga jual standar pula; produk dawet tidak dapat awet pada suhu ruang, dan terbatasnya pengetahuan tentang olahan bahan lain sehingga takut mencoba peluang bisnisnya. Hasil diskusi ini menjadi dasar pemberian materi penyuluhan dan pelatihan.

\section{Metode}

Kegiatan pengabdian ini dilakukan pada bulan April 2019 selama 5 hari bertempat di Laboratorium Terpadu FKIK UKSW dengan peserta terpilih sebanyak 25 orang. Peserta kegiatan merupakan pelaku UMKM sector usaha kaki lima yang bergerak pada produk makanan dan minuman olahan di Kota Salatiga binaan DINKOP UMKM Salatiga.

Kegiatan penyuluhan dan pendampingan dilakukan dalam dua sesi, yaitu pertama: sesi dinamika kelompok yang bertujuan untuk menggali informasi kebutuhan dan harapan peserta selama mengikuti kegiatan ini. Berdasarkan hasil sesi inilah diberikan materi penyuluhan yang terkait pada sesi selanjutnya. Secara keseluruhan pengisi sesi penyuluhan terdiri dari pihak pemerintah Kota Salatiga, dan dari akademisi sebanyak 6 orang. Namun yang akan dipaparkan secara khusus adalah sesi penyuluhan tentang inovasi olahan umbi singkong. Setelah keseluruhan sesi penyuluhan selesai maka bagian kedua selanjutnya adalah praktik pembuatan beberapa menu inovatif.

Adapun menu praktik olahan umbi singkong yang diberikan adalah cassava lava, sawut coklat, dan cake singkong keju. Untuk praktik menu diatas, keperluan alat dan bahannya sebagai berikut:

\section{1). Cassava lava}

Bahan - bahan : Singkong setengah tua $1 \mathrm{~kg}$, garam $1 \mathrm{sdt}$, gula pasir $4 \mathrm{sdm}$ (atau sesuai selera), coklat bubuk, vanili 1 sachet, terigu segitiga 3-4 sdm, minyak goreng $500 \mathrm{ml}$. Isian: Coklat blok (merk Collata) di tim, keju oles (merkProchiz).

Alat - alat: pisau, talenan, panci kukus, serbet katun, saringan, loyang aluminium, sendok makan.

Langkah pembuatan:

1. Siapkan dan takar bahan mentah sesuai takaran.

2. Singkong setelah dikupas, cuci, dan kukus hingga empuk lalu ditumbuk sampai halus. Tambahkan garam, gula pasir, 
Abditani : Jurnal Pengabdian Masyarakat 2 (2) 67-72

e-ISSN : 2622-4690

p-ISSN : 2622-4682

vanili, aduk hingga menyatu rata. Tambahkan terigu sebagai perekat

3. Adonan dibagi dua. Satu bagian dicampurkan bubuk coklat, bagian lain dibiarkan polos.

4. Ambil adonan $\pm 40 \mathrm{gr}$, bentuk bulat lalu dipipihkan, masukkan sesuai isiannya.

5. Goreng dalam minyak yang panas hingga berwana kuning keemasan. Lalu diangkat dan ditiriskan.

\section{2). Sawut coklat}

Bahan - bahan : Singkong $1 \mathrm{~kg}$ setengah tua, bubuk coklat, gula pasir $12 \mathrm{sdm}$ (atau sesuai selera), kelapa parut setengah tua. Topping: sawutan coklat batang, atau keju cheddar, minyak untuk olesan cetakan.

Alat- alat : pisau, talenan, panci kukus, serbet katun, cetakan kue aluminium, kuas kue, parutan keju, loyang aluminium.

Langkah pembuatan:

1. Terlebih dahulu siapkan kukusan. Tutup panci diberi serbet dibagian dalam.

2. Singkong dikupas, cuci dan parut kasar. Parutan singkong kasar ditambahkan gula pasir (test rasa). Lalu adonan dibagi dua bagian. Satu bagian ditambahkan bubuk coklat, satu bagian ditambahkan parutan kelapa.

3. Olesi cetakan dengan minyak sayur. Masukkan sawutan coklat setengah volume cetakan, padatkan, lalu timpa sawutan putih. (Bisa juga sebaliknya)

4. Kukus sawut hingga matang $( \pm 10-15$ menit). Angkat dan sajikan.

\section{3). Cake singkong keju}

Bahan - bahan : Singkong parut $1 \mathrm{~kg}$, mentega 150gr, gula 150gr, telur 4btr, fermifan 1bks dalam $150 \mathrm{ml}$ air hangat, kental manis 2 sachet, terigu $150 \mathrm{gr}$, garam dan vanili secukupnya. Topping: Coklat chip, keju.

Alat - alat : Parutan kelapa, parutan keju, sendok takar, mangkok kecil, timbangan makanan, Loyang aluminium ukuran 20 x 10 $\mathrm{cm}$.

Langkah pembuatan :

1. Parut singkong, peras sampai kering. Sisihkan
2. Campurkan mentega dan gula sampai rata, masukkan telur bertahap hingga telur putih kaku.

3. Masukan terigu aduk rata, kemudian singkong parut, garam, kental manis, dan vanili.

4. Tambahkan larutan fermifan, dan kental manis.

5. Taburi keju parut dan coklat chip, dan panggang selama 45 menit.

\section{Hasil dan Pembahasan}

Hasil kegiatan ini dibagi atas dua tahap, yaitu penyuluhan, dan praktik olahan makanan terkait.

I. Penyuluhan tentang inovasi olahan umbi singkong.

Materi mencakup pengertian umbi, sejarah singkong masuk ke Indonesia dan perkembangannya hingga sekarang, nilai gizi umbi singkong serta inovasi olahannya. Umbi sebagai bagian tanaman yang membesar dalam tanah umumnya mengandung pati. Pati pada singkong kaya karbohidrat namun miskin protein dalam kualitas dan kuantitasnya (lihatTabel 1), mengandung sianogen dan senyawa antinutrisi (Salvador, Steenkamp, \& Mc Crindle, 2014). Umumnya pati lazim dikonsumsi sebagaisalah satu makanan pokok manusia ataupun sebagai persediaan pangan (Falade \& Akingbala, 2010). Diketahui pula bahwa karbohidrat dalam umbi-umbian bersifat kompleks sehingga agak lama dicerna oleh enzim pencernaan manusia. Sifat ini menyebabkan rasa kenyang lebih lama, dengan demikian mencegah terjadinya kenaikan gula darah secara cepat.

Singkong termasuk dalam family Eufobiaceae dan merupakan tanaman umbi terpenting di negara tropis. Singkong pertama kali di kenal di Amerika Selatan, diintroduksi ke Afrika Tengah pada akhir abad ke-16. Menyebar ke Afrika Tengah hingga ke Afrika Barat dan Afrika Timur pada abad ke-19 (Anikwe \& Ikenganyia, 2018). Pada abad ke-16 Portugis menjajah Maluku dan mengenalkan tanaman singkong. 
Singkong menjadi tanaman komersial pada saat penjajahan Hindia Belanda tahun 1820. Singkong atau ketela pohon dipakai dalam bahasa Melayu. Istilah "ketela" dianggap berasal dari bahasa Portugis "castilla" sebuah istilah untuk Spanyol. Umbi singkong dapat dipanen kapan saja tanpa mengenal musim, selain itu dapat mengenyangkan menjadi alasan kuat ketika masyarakat Indonesia dipaksa untuk membudidayakannya. Sekitar abad ke-20 penanaman singkong semakin pesat seiring pertambahan penduduk pulau Jawa, dan mengakibatkan pertumbuhan padi tertinggal. Saat ini singkong dikenal sebagai bahan makanan pokok yang ke-3 setelah padi dan jagung. Umumnya singkong diolah menjadi tapioka lalu tapioka ini dimanfaatkan sebagai bahan baku lem, permen karet, tekstil, dan furniture.

Secara anatomi umbi singkong terdiri dari berapa lapisan kulit yaitu: kulit luar, kulit dalam, daging umbi, dan empulur. Antara kulit dalam dan daging umbi terdapat kambium yang licin berlendir. Kambium ini mengandung enzim Polifenolase penyebab umbi berwarna coklat kehitaman. Pada daging dan kulit singkong terdapat mengandung linamarin dan Lotaustralin (precursor asam sianida) (Cardoso et al., 2005); (Salvador et al., 2014). Jika linamarin bertemu dengan air akan menghasilkan Dglukosa dan aseton sianohidrin yang bersifat racun. Secara alami, dalam singkong terkandung asam sianida sekitar $20-1000$ $\mathrm{mg} / \mathrm{kg}$ umbi segar atau sekitar 118,9 ppm per 2 gram umbi, dimana jumlah ini dapat berubah tergantung jenis singkongnya dan musim saat dipanen (Franck et al., 2011). Singkong untuk keperluan industri umumnya berasa pahit dan mengandung asam sianida $\geq$ $50 \mathrm{mg} / \mathrm{kg}$ singkong segar, sedangkan singkong untuk konsumsi mengandung asam sianida $\leq 50 \mathrm{mg} / \mathrm{kg}$ singkong segar. Masyarakat Indonesia telah mengenal cara cara tradisional dalam mengurangi racun pada bahan pangan sebelum dikonsumsi, misalnya pada singkong lazim dilakukan perendaman beberapa jam dalam air mengalir, perebusan, pengukusan,dan fermentasi. Menurut (Cardoso et al., 2005), kandungan sianida dapat dikurangi dengan cara pengeringan sinar matahari, penyangraian, dan fermentasi tumpuk. Komposisi proksimat umbi singkong segar disajikan dalam Tabel 1.

Tabel 1. Komposisi proksimat umbi singkong segar

\begin{tabular}{ll}
\hline Jenis Proksimat & $\%$ \\
\hline Kadar Air & $65-70$ \\
\hline Pati & 21.5 \\
\hline Protein & $0.7-1.1$ \\
\hline Lemak & 0.42 \\
\hline Serat & 1.10 \\
\hline Abu & 0.54 \\
\hline Bahan kering & $35-38$
\end{tabular}

Sumber: IITA dalam (Falade \& Akingbala, 2010)

Berdasarkan nilai nutrisinya ini pada suatu masa pemerintah Indonesia mempopulerkan semacam slogan pengganti nasi sebab lebih sehat, harga merakyat, namun rasa pejabat. Sampai saat ini penggunaan singkong dalam olahan pangan belum bisa sepenuhnya lepas dari pengaruh terigu. Maka dikembangkanlah tepung singkong tanpa gluten yaitumocaf(starch modification)yang diklaim lebih sehat daripada tepung terigu. Pati modifikasi dapat dikelompokkan menjadi beberapa kelas yaitu pati modifikasi secara fisika, kimiawi, enzimatik, dan biologik. Diantara kelompok tersebut, modifikasi pati secara kimiawi lebih sering dilakukan. Modifikasi secara kimiawi ini menggunakan reagen khusus dan hasilnya lebih cepat. Pati modifikasi ini lebih tahan panas, tahan asam, dan memiliki daya renggang kuat dibanding pati aslinya(Gunorubon \& Kekpugile, 2012), sehingga cocok diaplikasikan pada produk produk pangan yang membutuhkan tekstur kenyal, dan elastis seperti mie, pasta, dan roti-rotian. Dewasa ini pembuatan mocaf masih dikalangan tertentu saja bahkan ada yang dipatenkan sehingga harga jualnya menjadi lebih mahal, yaitu sekitar 16 ribu per kilo. Harga ini merupakan dua kali lipat dari harga terigu yang beredar di pasaran. Terlepas dari kebaikan yang dihasilkan oleh mocaf, masyarakat awam masih dapat 
berinovasi banyak tentang olahan singkong dari singkong segar terutama trend makanan saat ini adalah kembali kealam. Segala sesuatu sedapat mungkin dibuat sedemikian rupa sehingga terlihat alami namun dikemas secara modern dan memiliki fungsi khusus terhadap kesehatan.

Beberapa olahan singkong tradisional yang lazim dikenal seperti kripik singkong, mataroda, gathot, combro, sentiling, gethuk, donat, tape, lemetsingkong, dan lain sebagainya. Kue - kue basah tradisional ini akan lebih dihargai jikadapatdisajikan dalam sentuhan modern, apalagi jika memiliki nilai fungsional tertentu. Pada saat pemaparan materi tentang inovasi umbi singkong berlangsung, peserta sangat antusias sehingga pemateri dihujani dengan banyaknya pertanyaan dari peserta. Sebelumnya, dengan berbekal evaluasi dari kegiatan tahun sebelumnya bahwa suasana kelas harus dibuat lebih atraktif supaya peserta tidak bosan dan mengantuk, maka kelas kali ini dibuat lebih menarik dan bahan lebih ringkas meskipun usia peserta relative sama dengan usia peserta pada kegiatan tahun sebelumnya yaitu didominasi usia $>45$ tahun. Berikut Gambar 1 saat sesi penyuluhan tentang umbi singkong berlangsung.

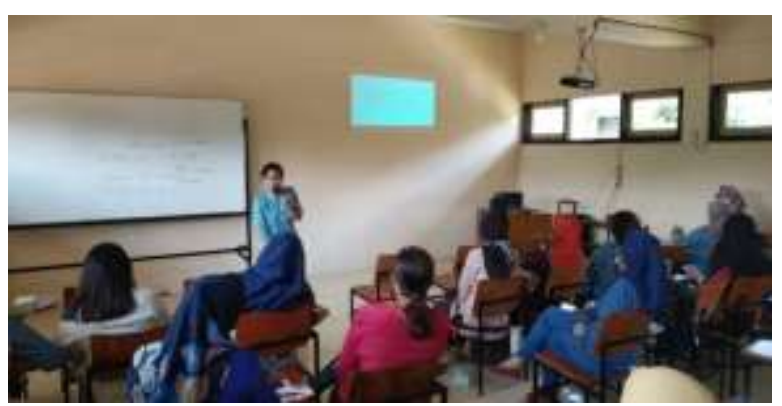

Gambar 1. Pemaparan materi inovasi olahan singkong (Sumber: Sie. Pubdekdok, 2019)

\section{Praktik Pembuatan Olahan Singkong}

Hasil praktik inovasi olahan singkong disajikan pada Gambar 2.

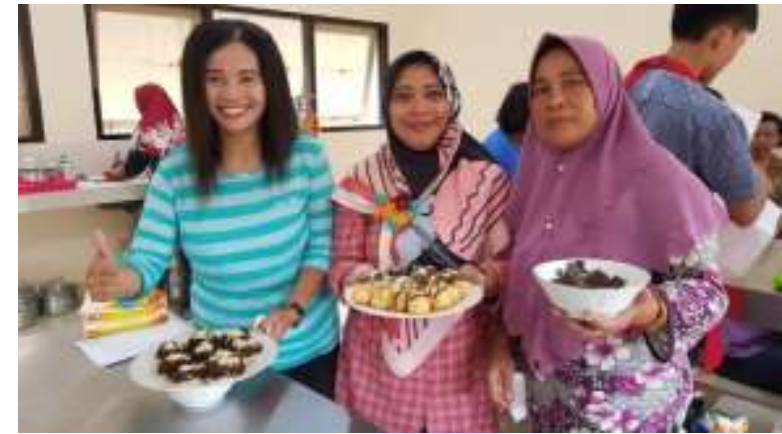

Gambar 2. Produk inovasi singkong (Sumber: Sie. Pubdekdok, 2019)

Alasan utama pemilihan menu ini adalah menyesuaikan pangsa pasar food street mengingat pesertanya adalah pedagang kaki lima yang membutuhkan inovasi dalam dagangannya, dengan konsep easy handling, awet, dan dapat dikemas secara ringkas ataupun secara modern.

Keseluruhan kegiatan berjalan sangat baik dan lancer tanpa ada hambatan yang berarti. Setelah kegiatan selesai, langsung diadakan evaluasi kegiatan. Para peserta menyatakan sangat beruntung sekali dapat terpilih mengikuti kegiatan ini sebab mereka mendapat berbagai pengetahuan yang baru dan ide baru untuk inovasi produk dagangannya. Peserta juga menyatakan agar ada pendampingan langsung dari pemateri khususnya dari pemateri kelas pengolahan pangan, dan pada waktu yang akan datang kegiatan serupa di adakan kembali.

\section{Kesimpulan}

Kegiatan penyuluhan dan pendampingan pelaku UMKM sektor kaki lima makanan dan minuman berjalan baik dan lancar. Peserta sangat mengapresiasi pengetahuan baru dan ide baru yang didapatkannya untuk inovasi produk jualannya. Selain itu mereka berharap pada pendampingan langsung dengan para pemateri yang terkait bahan utama produk dagangannya.

\section{Daftar Pustaka}

Anikwe, M. A. N., \&Ikenganyia, E. E. (2018). Ecophysiology and Production Principles of Cassava (Manihot species) in Southeastern Nigeria. In Cassava. https://doi.org/10.5772/intechopen.70828

Cardoso, A. P., Mirione, E., Ernesto, M., Massaza, F., Cliff, J., Rezaul Haque, M., \& Bradbury, J. H. (2005). Processing of cassava roots to remove cyanogens. Journal of Food Composition and 
Abditani : Jurnal Pengabdian Masyarakat 2 (2) 67-72

Analysis, 18(5), 451-460. https://doi.org/10.1016/j.jfca.2004.04.002

Chavarriaga-Aguirre, P., Brand, A., Medina, A., Prías, M., Escobar, R., Martinez, J., ... Tohme, J. (2016). The potential of using biotechnology to improve cassava: a review. In Vitro Cellular and Developmental Biology - Plant. https://doi.org/10.1007/s11627-016-9776-3

Falade, K. O., \&Akingbala, J. O. (2010). Utilization of Cassava for Food. Food Reviews International, 27(1), 51-83. https://doi.org/10.1080/87559129.2010.51 8296

Franck, H., Christian, M., Noël, A., Brigitte, P., Joseph, H. D., Cornet, D., \& Mathurin, N. C. (2011). Effects of cultivar and harvesting conditions (age, season) on the texture and taste of boiled cassava roots. Food Chemistry, 126(1), 127-133. https://doi.org/10.1016/j.foodchem.2010.1 0.088

Gunorubon, J., \&Kekpugile, K. (2012). Modification of Cassava Starch for Industrial Uses. International Journal of Engineering and Technology, 2(6), 913919. Retrieved from http://citeseerx.ist.psu.edu/viewdoc/downl oad?doi=10.1.1.411.8134\&rep=rep1\&type $=\mathrm{pdf}$

Latif, S., \& Müller, J. (2015). Potential of cassava leaves in human nutrition: A review. Trends in Food Science \& Technology, 44(2), 147-158. https://doi.org/10.1016/j.tifs.2015.04.006

Montero, W. R. (2003). Cassava; Biology, Production and Utilization. Crop Science, 43(1),448.

https://doi.org/10.2135/cropsci2003.4480

Morgan, N. K., \&Choct, M. (2016). Cassava: Nutrient composition and nutritive value in poultry diets. Animal Nutrition. https://doi.org/10.1016/j.aninu.2016.08.010

Palimbong, S., Nurwarista, A., \&Istimur, S. M. (2019). POTENSI PEMANFAATAN SUMBER TEPUNG LOKAL SEBAGAI. InovatifPengabdian Masyarakat, 2(2), 1-6. Retrieved from https://jipm.unisapalu.ac.id/index.php/jipm /issue/view/4

Salvador, E. M., Steenkamp, V., \& Mc Crindle, C. M. E. (2014). Production, consumption and nutritional value of cassava (Manihot esculenta, Crantz) in Mozambique: An overview. Journal of Agricultural Biotechnology and Sustainable Development. https://doi.org/10.5897/jabsd2014.0224 